\title{
Environmental Diplomacy: A Framework for Growth of International Interaction and Cooperation for Achievement of Global Peace
}

\author{
Sobhan Tayebi ${ }^{1}$, Seyed Fazlollah Moosavi ${ }^{2} \&$ Seyed Abbas Poorhashemi ${ }^{3}$ \\ ${ }^{1}$ Department of Environmental Law, Faculty of Environment and Energy, Science and Research Branch, Islamic \\ Azad University, Tehran, Iran \\ ${ }^{2}$ Faculty of Law and Politic, University Of Tehran, Tehran, Iran \\ ${ }^{3}$ Department of Environmental Law, Faculty of Environment and Energy, Science and Research Branch, Islamic \\ Azad University, Tehran, Iran \\ Correspondence: Seyed Fazlollah Moosavi, Faculty of Law and Politic, University Of Tehran, Tehran, Iran. \\ E-mail: sfmoosavi12@chmail.ir
}

Received: May 19, 2016 Accepted: July 18, 2016 Online Published: October 30, 2016

doi:10.5539/jpl.v9n9p150 URL: http://dx.doi.org/10.5539/jpl.v9n9p150

\begin{abstract}
Protection of the Environment nowadays is the top Priority on the Agenda of the International Community of Decision-Makers. The increasing Importance of the Issue Is Due To The Fact That Minor National Environmental Crises Have Developed into Major International ones. Surely Sustainability in Development and Environmental Protectiondoes not occur without Serious Regional Interactions And International Cooperation. Hence, Despite the Improved International Relations And Capacities As Well As The Existing Mechanisms, Inter Alia, The International Rules, The Global Community should attempt Towards Interactions To Protect The Global Security against Major Challenges and Keep Global Peace in a stable process. Hence, Environmental Diplomacy Is a Major Issue that is Efficient in the Interactions among Countries and, Ultimately, Citizens, Adding to the Depth of Peace and Security. In This Direction, Constructive Interactions on a National Scale As well As Effective Interactions on Regional and International Scales form An Effective Strategy to encounrer Increasing Environmental Threats. The Aim of This Study Is discussion And An Exploration of Environmental Diplomacy In Light Of International Interactions And Cooperation.
\end{abstract}

Keywords: environmental diplomacy, international interactions, international cooperation, global peace, future of perspective

\section{Introduction}

Today, protection of the environment within the context of effective international rules with a view to qualitative strategies and quantitative strategies (Poorhashemi et al., 2012). In this context, there are effective valid judicial precedents which make notable contributions to modelling for the protection of the environment within the context of International Environmental Law (Mousavi, 2012). In this context, the efforts of the international community help to realize compliance with the working procedures of international treaties aimed at efficiently protecting the environment in such a manner as to prevent the ecosphere from getting exposed to the emerging environmental threats and preventing the global peace from stressful conditions. With these initiatives, international commitments and allegiance to them substantially arise. Such interactions and allegiance to commitments organize the framework of environmental diplomacy in the light of joint responsibility. For this reason, it can be said that the purpose of environmental diplomacy is to eliminate environmental stressors. In this study, by describing the environmental diplomacy, the major axes of international interactions and global peace could be explained in step with the human environmental rights.

\section{Environmental Diplomacy in Light of International Dialogs}

Regional and international constructive interactions are the most strategic and most effective procedures to protect the political, economic, and security interests which take on a more authentic form. In this context, concern for environmental security with a view to environmental diplomacy is the most valuable activity in the international arena and relations. Sustainability of development and sustained development on the way to development and unquestionable protection of the environment and natural resources are intended to protect the 
common human heritage. On the way to internalization or globalization, development occupies a special place. This specialty is important in that it carries along the sustainability feature. Reference to the fact seems necessary that unsustainable development would disrupt the globalization process leading the world to an abyss of crisis. Simply, should the purpose be development only, devoid of sustainability, the ecology and ecosphere would be destroyed. This is not an advertising message, and that presently, the world is not in a good condition environmentally. Moreover, the environmental crises and hazards, climatic changes included, have the world today in their grips. Therefore, a sustainable environment and globalization go hand in hand. Hence, it would be more befitting to be environment-conscious on the way to ideology-consciousness (Tayebi,A. 2013). Environmental diplomacy is an effective tool, a solid strategy and reliable procedure for synergy, regional and international cooperation aimed at reinforcing and sustaining the protection of the ecosphere and the joint human heritage (Tayebi,B. 2013).Thus, the right to the environment is, inter alia, the human right which on the way to development is classified within the human rights discourse. Protecting this process and its expression in the context of formal relations has taken on a serious form and, in a sense, sustains the rights of coexistence in the light of international convergence. Hence, a fixative, protective and effective mechanism for the right to the environment comprises the environmental diplomacy (Zaree et al., 2016). In this connection, the relation between the human rights and environmental protection with special emphasis on the rights of nations is of paramount importance. This is so because the entire right to the environment is, among other things, the most important bases of the international environmental rights as well as the structural foundations of the environmental and human rights discourse.

\section{Environmental Diplomacy and International Interactions and Cooperation's}

In the international arena, there is no other alternative than peaceful interactions. Environmental diplomacy is affected by international and global diplomacy and subject to the character and form of the rule. In this context, to realize the environmental diplomacy, emphasis is on security and environmental frameworks with a view to bond-based indices on the axes of diplomacy and Environment. International cooperation has always helped solve many of the international problems such as environmental hazards which call for specific mechanisms to work effectively. This is not to say that without regional synergy and international cooperation, environmental diplomacy would fail (Tayebi and Mirtorabi, 2014).

In view of the above, successful diplomacy requires the all-out cooperation of ecosphere inhabitants, the authorities in particular, to protect the environment in the habitat. This is extremely important because, depending on how they are managed, the natural resources and environment can function as a source of tension and conflict and a ground for cooperation. With this approach, environmental diplomacy is defined as a combination of tools and methods helping the parties in conflict by addressing the problems common to both the environment and natural resources in order to create an opportunity for cooperation, building confidence and bypassing tension. Therefore, international cooperation aimed at protecting the global environment is of vital importance both to the global communities and the people across the world. With this in mind, environmental diplomacy could play a positive role in elucidating the international interactions at a time when the pathology of the environment and natural resources is at issue (Hartmann, 2007). Hence, it should be noted that the environment could not only help to create tension but to always fall, directly or indirectly, victim to the tensions, and that destruction of the environment would have no other aftermath than threats to health, living and security of the people (Mattew and Brown, 2009). Thus, Environmental Diplomacy Is a New Approch In the Light of International Interactions and Cooperations. The success of Environmental Diplomacy.is rooted in Compliance with common international obligations.

\section{Environmental Diplomacy and Environmental Protection}

The necessity of environmental protection is a complicated problem in international law, and different factors are involved in internationalization of this protection. This Trend about the environment should not lead to ignoring the commitments of the global community in either the developing or industrialized communities. The environmental issue must be placed in its proper panorama both in the developing and developed countries. The environmental decline has continued despite promotion of environmental agreements made internationally and the new environmental challenges emerging continually. Despite the large number of international agreements, there is a great potential for the conflict of rules and agreements, inconsistency of obligations, a huge gap in meeting the expectations, and for the aims and responsibilities to become repetitive. The international environmental law developed in a step-wise fashion, and the large number of treaties having grossly failed to materialize the international agreements have played their parts (Tayebi,B. 2013). Part of the explanation for the failure of the international environmental law in investigating the environmental challenges lies in the fact that in the course of the development of the international environmental law, little attention has been drawn to the effect 
of this part of the new law. The effect of the international environmental law on reactions to the new emerging environmental challenges partly relates to us who escape the harmful effect or influence of the broad sense of sovereignty in international law. It is clear to think that international relations and international politics are shaped by a single-nationality country. However, it is not a single nationality that can resolve the environmental problems; rather, the requirement for overcoming these problems and complications are constructive international interactions in the form of specific international relations that can be referred to as environmental diplomacy (Tayebi,A. 2013).

Environmental Diplomacy and Environmental Protection have two main pillars: First, Compliance and Implementation of Treaties and Second, Conservation and Protection of the Environmental Obligations. (Tayebi, 2016) Therefore, In order to prevent any type of environmental perils, international communities need to cooperate, and countries with flexible regulations should move towards those with strict ones.

\section{Environmental Diplomacy and Global Peace}

Human rights discourse on the right to the environment and protection of the environment in the context of environmental diplomacy prepares the ground for global diplomacy. In this context, constructive interactions and valuable cooperation on a regional and international scale could sustain biological existence and guarantee global peace. In any event, today, the threats from the newly-emerging environmental phenomena have confronted the ecosphere with unprecedentedly further hazards of destruction (Larry and Supati, 2014). In this context, environmental diplomacy plays its part to direct and execute the international environmental agreements (Buhaug, 2010). This is the same effective strategy for environmental diplomacy and its effect on international interactions. Although the responsibilities are shared and yet different, the world will not tolerate irresponsibility, and that irresponsibility and violation of this important consideration will ensue international liability and payment for the damage.

Therefore, it is clear that if new environmental challenges occur, we need to think carefully whether we need new laws and institutions, or we need to use appropriate mechanisms in existing laws, or we need to adapt our existing mechanisms to new challenges. (Tayebi et al., 2015) A Precise analysis of the role of people's participation and their access to information in achieving sustainable development and good management of the environment is another issue in today's environmental discussions. The close relationship between sustainable development and clarity through accessibility to information is influential in achieving desirable environmental goals. In this regard, the relationship between human rights and environmental protection, specifically rights of nations, is very important. (Tayebi and Esmaeilifard, 2016)

The general right to the environment is one of the most important bases of international environmental law and is a structural foundation for environmental and human rights discourse. This is where international relations helps, and regional, international, and global cooperation play their role. Realized officially or publicly, it is the specific viewpoint towards environmental international interactions that is shaped by environmental diplomacy.

\section{Green Diplomacy and Future of Perspective}

International political trends are increasingly being confronted with or accompanied by a broad spectrum of environmental problems of concern. Now the reasoning and current arguments indicate that the indisputable sovereignty of the national government is a way to improve international cooperation in countering environmental problems. This procedure is an integral part of the environmental diplomacy. The cooperation must continue to enhance awareness of the brittleness of the natural environment which calls for further effort and that collective measures must be taken to stop the destructive method (Koivurova, 2015). From this perspective, we can vividly see the sunrise of the New Global Order from whose rich standard all will benefit. By Green Diplomacy is meant sorting out the international problems of running a government in countering the world of nature, its countless problems and the current extremely difficult challenges in the international arena where there has to be constant progress and small steps taken to create a legal framework guaranteeing the environmental standards (Kelman, 2003). This is not a self-contained scenario; however, concerning international mechanisms and problems, it has been said there are efforts to negotiate with a view to the ruling means of governments which reasonably and realistically consider their national interests in protecting their rights of sovereignty (Brood head, 2002). From a global perspective, we have deepened the destruction of the environment such that it seems very difficult to continue the path. The international environmental problems which have outgrown the details of individual problems are in fact the fault of the green diplomats who have made the mistake of having prepared the ground for the death of the environment (Zhang et al., 2007). 


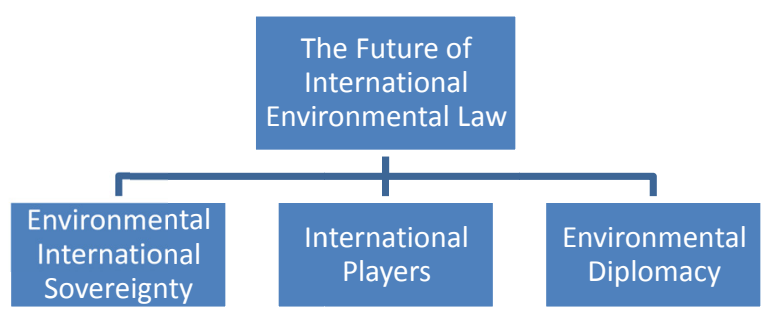

Accordingly, Environmental Diplomacy Could be the centerpiece of international interactions, and Changes Power Hegmonic For the benefit of biosphere. Therefore, the future of International Environmental Diplomacy and Law will be an ever changing phenomenon, just like the global environment itself.

\section{Discussion and Conclusion}

\subsection{Discussion}

The Study Discussed Growth Internatial Interaction, with an emphasis on the International Cooperation in Achievement of Global Peace. The Framework of Environmental Diplomacy exists to International Obligation Practice and Is the Basis for Impelimention Obligations. Regarding environmental protection, every country should share its expertise, and keep in unity with others. It is conceivable that some countries are not still familiar with the concept of "Diplomacy", hence, they make no effort towards it. Due to a multitude of problems and challenges pressing on them, the developing countries have become consumers only. This will slow down the trend of diplomacy for it seems that colonialism and exploitation have not left the countries yet. Every day in the course of its development, the global order undergoes change which calls for human interaction, i.e. international relations which assume a substantial form on the basis of diplomacy. In this process, goal-oriented diplomacy can guarantee the survival of the human community and human life preserving the common interests with a view to observing the international commitments and the governing rules (Tayebi et al., 2015). Diplomacy, be it public (with a national attitude) or formal (with an international attitude) must operate in a goal-oriented fashion. This orientation proceeds to the extent that it guarantees stability and global peace.

\subsection{Conclusion}

Today environmental diplomacy is a major international and global issue to which the attitude is peculiar. This peculiarity stems from the fact that human life is affiliated to it. The struggle of the international community to preserve the natural resources and yet to promote the quality of human life with a view to the human rights and status is based on justice, the sovereignty and law of a fundamental approach oriented towards sustained development. Environmental diplomacy must not be left priority-free for it can be viewed as facilitative of the trend of defensive diplomacy in the region. The view in fact elucidates the diplomacy of biological security shaped within the framework created by the intersection of two axes of diplomacy: environmental and defensive. Finally, it must be admitted that diplomacy exists thanks to the formal and informal frameworks. However, here the emphasis is on the fact that it has miserably failed to realize in communities, causing unwanted international environmental consequences which in fact might be due to the inflexibility of the formal environmental diplomacy although the inflexibility indicates the improper procedure used by parties to the diplomacy because the reverse trend must take place in some fully flexible state. The flexibility form, be it in a formal or informal space, will be effective within the framework of a defensive diplomacy.

Maintaining of relations requires development of modern and clean technologies in all countries. International Interactions should be that all the world could act in a unified manner, and benefit from the existing technologies. Accordingly, we cannot ignore the role of environmental diplomacy, since the development of international environmental law is indebted to that and positive Interactions. Environmental diplomacy is one of the basic effective ways of interaction between countries and people, and can ultimately reinforce peace and friendship. Environmental diplomacy is a substantial framework for global environmental protection and sustainable development. However, every country is expected to adhere to international agreements if the current situation of the world is expected to change. According to the above, it seems environmental diplomacy is one the most effective strategies for protection and sustainable development in the biosphere.

\section{Acknowledgement}

I Strongly Appreciate All Colleges For Their Kind Corporation. 


\section{References}

Brood head, LA. (2002). International Environmental Politics: the limits of Green Diplomacy, Lynne rienner publication, p. 32

Buhaug, H. (2010). Reply to Burke et al.: bias and climate war research. Proceedings of the National Academy of Sciences, 107(51), E186-E187. http://dx.doi.org/10.1073/pnas.1015796108

Hartmann, B. (2007). Climate Refugees and Climate Conflict: Who's Taking the Heat for Global Warming?, Paper delivered at the panel on Climate Change, 4S Annual Conference Montréal, Québec, 11 October 2007 and draft in progress, p. 11.

Kelman, I. (2003). Beyond Disaster, Beyond Diplomacy. In M. Pelling (Ed.), Natural Disasters and Development in a Globalizing World (Chapter 7, pp. 110-123). Routledge, London, U.K.

Koivurova, T. (2015). Introduction To International Environmental Law,(S. Tayebi And M, Zarabi, Trans), Mizan Legal Fundation, p. 301-302.

Larry, D., \& Supati, B. (2014). the Future Of International Environmental Law In The Age Of Globalization (S. Tayyebi And S. Tayyebi, Trans.). Presidential Administration's National Center for Globalization, p. 176.

Mattew, R., \& Brown, O. (2009). From Conflict to Peace building: The role of natural resources and the environment, p. 3.

Mousavi, S. F. (2012). History of the Development of International Sources of Law (2nd ed.). Tehran: Mizan Publishers. p. 569.

Poorhashemi, S. A., Taghavi, L., \& Poushaneh, N. (2012). A Study of the International Rights Regimens for the Protection of the Persian Gulf Environment, Qeshm. Collection of Articles presented on the First International Conference on the Environment and Geopolitics of the Persian Gulf, p. 2.

Tayebi, S. (2013a). Environmental Diplomacy: Current Views on Environmental Protection and Human Rights. Extracted from the Daneshmandane Hoghoughe Irane Farda. P. 3-7.

Tayebi, S. (2013b). Environmental Diplomacy: An Effective Process for Global Environmental Protection. Extracted from the Daneshmandane Hoghoughe Irane Farda. P. 1-4.

Tayebi, S. (2016). Environmental Diplomacy and International Sustainable Development(Views and Opinions), Majd Law Publication, PP. 88-90.

Tayebi, S., \& Esmaeilifard, M. (2016). International Environmental Diplomacy; In the Light of Negotiations and International Decision- Making, Majd Law Publication, PP. 138-144.

Tayebi, S., \& Mirtorabi, H. (2014). Environmental Diplomacy: An Effective Approach Towards Protection And Sustainable Development. Proceedings of the 2nd National Conference on Planning, Environmental Protection, and Sustainable Development. Hegmataneh Institute, Shahidbeheshti University, p. 3-6.

Tayebi, S., Moosavi, S. F., \& Poorhashemi, S. A. (2015). Environmental Diplomacy In The Light Of International Convergence: An Effective Approach Towards International Interaction And Sustainable Peace. Kasmera Journal, 43(2), 31.

Zaree, A., Tayebi, S., \& Naderi, S. (2016). Environmental Diplomacy in Light of International Interactions; Approach Effective in Attaining International Law Sustainable Development, 21National and Regional Conference Iranian Society of Environmentalist, Science and Research Branch, Islamic Azad University of Tehran, pp. 8-11.

Zhang. D. D., Zhang, J., Lee, H. F., \& He, Y. Q. (2007). Climate Change and War Frequency in Eastern China over the Last Millennium. Human Ecology, 35, 403-414. http://dx.doi.org/10.1007/s10745-007-9115-8

\section{Copyrights}

Copyright for this article is retained by the author(s), with first publication rights granted to the journal.

This is an open-access article distributed under the terms and conditions of the Creative Commons Attribution license (http://creativecommons.org/licenses/by/4.0/). 